\title{
Amphiregulin enhances intercellular adhesion molecule-1 expression and promotes tumor metastasis in human osteosarcoma
}

\author{
Ju-Fang Liư ${ }^{1}$, Ya-Ting Tsao ${ }^{2}$, Chun-Han Hou ${ }^{2}$ \\ ${ }^{1}$ Central Laboratory, Shin-Kong Wu Ho-Su Memorial Hospital, Taipei, Taiwan \\ ${ }^{2}$ Department of Orthopedic Surgery, National Taiwan University Hospital, Taipei, Taiwan \\ Correspondence to: \\ Chun-Han Hou, e-mail: chhou@ntu.edu.tw
}

Keywords: amphiregulin, osteosarcoma metastasis, cell migration, ICAM-1, EGFR

Received: May 21, 2015

Accepted: September 13, 2015

Published: October 19, 2015

\section{ABSTRACT}

\begin{abstract}
Osteosarcoma is a common, high malignant, and metastatic bone cancer. Amphiregulin (AREG) has been associated with cancer cellular activities. However, the effect of AREG on metastasis activity in human osteosarcoma cells has yet to be determined. We determined that AREG increases the expression of intercellular adhesion molecule-1 (ICAM-1) through PI3K/Akt signaling pathway via its interaction with the epidermal growth factor receptor, thus resulting in the enhanced cell migration of osteosarcoma. Furthermore, AREG stimulation increased the association of NF-KB to ICAM-1 promoter which then up-regulated ICAM-1 expression. Finally, we observed that shRNA silencing of AREG decreased osteosarcoma metastasis in vivo. Our findings revealed a relationship between osteosarcoma metastatic potential and AREG expression and the modulating effect of AREG on ICAM-1 expression.
\end{abstract}

\section{INTRODUCTION}

Osteosarcoma is a malignant neoplasm of the bone, which is prevalent in teenagers and young adults. The cause of osteosarcoma is unclear. However, numerous factors are associated with the increased risk of osteosarcoma including age, genetic inheritance, chronic inflammation, virus infection and radiation exposure [1]. Most patients with osteosarcoma are treated with chemotherapy or radiation therapy. However, some patients remain at high risk of relapse or metastasis, thus necessitating successful treatment [2]. Although surgery remains the vital modality for treating the primary tumor in such patients, adjuvant chemotherapy plays an essential role in controlling sub-clinical metastatic disease [3]. Because osteosarcoma has highly invasive and metastatic potential, determining the factors promoting metastasis of osteosarcoma is imperative [4].

Cancer metastasis is a complicated process involving several attachment and detachment events. Therefore, as expected, numerous studies have revealed a correlation between changes in cell adhesion, tumor invasion and metastasis [5, 6]. For example, loss of adhesion between cells enables malignant tumors cells to detach from the primary tumor and to enter the circulatory system. However, at the later stages of metastasis, expression of adhesion molecules facilitating intercellular contacts is required for efficiently spreading metastatic cells [7-9]. One of these cell adhesion molecules is intracellular adhesion molecule-1 (ICAM-1/ CD54), a member of the immunoglobulin supergene family [10-12]. ICAM-1, a surface glycoprotein, is expressed at a low basal level on the surface of leukocytes and endothelial cells. ICAM-1 is also constantly present at low concentrations in fibroblasts, keratinocytes, and epithelial cells, but is up-regulated in response to several inflammatory mediators [13]. Numerous studies have reported that ICAM-1 expression contributes to human tumor progression because elevated expression levels of this protein have been observed in gastric, pancreatic and breast cancer tissues, and the highest expression levels were observed in samples from patients with metastases [14]. Many studies have supported the potential involvement of ICAM-1 in the metastasis of certain tumors. For example, knockdown of ICAM-1 reduced the invasiveness of prostate cancer cells [15] and depletion of ICAM-1 inhibited melanoma lung metastasis [16]. ICAM-1 was also involved in the invasion of breast, lung, gastric, oral, and bone cancer cells $[10,15,17-19]$. 
In our previous study, we determined that elevated ICAM-1 expression was promoted the metastasis of osteosarcoma: the expression level of ICAM-1 was elevated in two metastatic osteosarcoma cell lines and ICAM-1 siRNA reduced their tumor cell migration (transforming growth factor alpha) [20]. Moreover we suggested that ICAM-1 expression is up-regulated by $\mathrm{PI} 3 \mathrm{~K} / \mathrm{Akt}$ signaling pathway through the epidermal growth factor receptor (EGFR) [20]. The EGFR is a receptor tyrosine kinase of the ErbB family. Upon activation by the binding of specific ligands, the autophosphorylation of the EGFR at several tyrosine residues initiates downstream signal transduction cascades, principally of the mitogenactivated protein kinase, Akt and c-Jun N-terminal kinase pathways. These protein kinases modulate several cellular activities such as cell migration, adhesion, and proliferation. Therefore the aberrant activation of EGFR has been associated with various cancers through several mechanisms including receptor overexpression, mutation, receptor ligand overexpression, and ligandindependent activation [21]. For example, overexpression of Transforming growth factor-alpha (TGF- $\alpha$ ), one of the main ligands of the EGFR, has been observed in various of malignant tumors such as kidney cancer, pancreatic cancer, colon cancer and breast cancer [22-25]. Furthermore, we have demonstrated in our previous study that TGF- $\alpha$ mRNA and protein level were higher in osteosarcoma cell lines and that TGF- $\alpha$ promotes osteosarcoma metastasis through its interaction with EGFR [20].

In addition to TGF- $\alpha$, amphiregulin (AREG) is another EGFR ligand that is known to promote cancer growth and progression. AREG is a member of the epidermal-growth-factor-like family [26, 27]. It can bind to and activate the EGFR through three general mechanisms: autocrine, paracrine, and juxtacrine. Therefore, it can regulate numerous cellular functions such as cell proliferation, survival, migration, differentiation, adhesion and angiogenesis [28-31]. Physiologically, AREG stimulates the proliferation of normal cells such as fibroblasts, keratinocytes, urothelial or epithelial cells $[32,33]$. Studies have reported that AREG plays a vital role in the development and maturation of various organs including the mammary glands [34, 35], bones [36], or placenta [37]. Nonetheless, AREG promotes the migration of tumor cells [38, 39] and its overexpression has been observed in several cancer tissues such as colorectal, gastric, pancreatic and breast cancer [40-43]. Moreover a microarray analysis revealed that AREG was up-regulated in metastatic tumors of the liver [44].

To understand the role of AREG in osteosarcoma metastasis, in the current study, we examined its expression level and the effect of exogenous AREG treatment in osteosarcoma cells. We determined that two osteosarcoma cell lines expressed high levels of AREG and that further AREG stimulation enhanced ICAM-1 expression, thus contributing to the increased cell migration of osteosarcoma. Using molecular and pharmacological approaches, we also found that the AREG-induced cell migration of osteosarcoma cells was mediated by EGFR signaling through its downstream PI3K/Akt pathway. Furthermore, increased EGFR signaling enhances the activity of nuclear factor $-\kappa \mathrm{B}(\mathrm{NF}-\kappa \mathrm{B})$ and the recruitment of NF- $\kappa B$ to the ICAM-1 promoter which subsequently up-regulate ICAM-1 expression. Our findings of the AREG-responsive signaling pathway provides valuable clues for understanding the mechanisms of human osteosarcoma metastasis and present an opportunity to develop highly effective clinical therapies in the future.

\section{RESULTS}

\section{AREG-induced cell migration in osteosarcoma cell line can be further enhanced by AREG supplementation, but be inhibited by ICAM-1 siRNA}

AREG has been shown to increase cell migration and metastasis in various human cancer cells [38, 39, 45]. To determine the clinical significance of AREG in patients with osteosarcoma, we utilized a tissue microarray for evaluation by IHC to compare the expression of AREG in normal bone and different grades of osteosarcoma. Representative examples of IHC staining for AREG in normal bone and osteosarcoma tissues with different grades are shown in Figure S1A-S1B. The expression of AREG had significantly increased with tumor progression (Figure S1A-S1B). Next, to understand the effect of AREG on osteosarcoma cells, we first determined the levels of AREG in two human osteosarcoma cell lines (MG63 and U2OS) and in one human fetal osteoblastic cell line (hFOB 1.19). The levels of AREG were significantly elevated in the MG63 and U2OS cells compared with the low basal level expressed in the hFOB 1.19 cell line (Figure 1A and Figure S1C). This finding is consistent with those of previous studies, suggesting that metastatic osteosarcoma is induced by the elevated AREG expression in the cells. To test this further, we supplied osteosarcoma cells with exogenous human AREG. We applied the Transwell assay to examine the AREGtriggered migration, and determined that AREG treatment further increased the migration of both the MG63 and U2OS cells in a dose-dependent pattern (Figure 1B). Furthermore, AREG treatment increased the woundhealing activities and cell motility of these cell lines [46] (Figure 1C), although it did not affect cellular viability in both human osteosarcoma cell lines (data not shown). To understand the level of AREG between the normal and the malignant cells, we examined the levels of AREG and ICAM-1 between hFOB 1.19 and osteosarcoma (MG63 and U2OS). The level of AREG and ICAM-1 were significantly elevated in MG63 and U2OS cell lines compared with hFOB 1.19 (Figure S1C). 
A

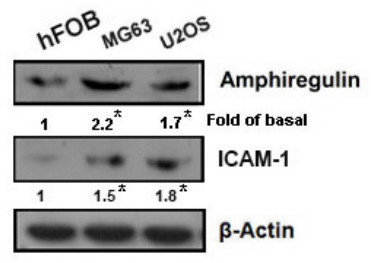

B

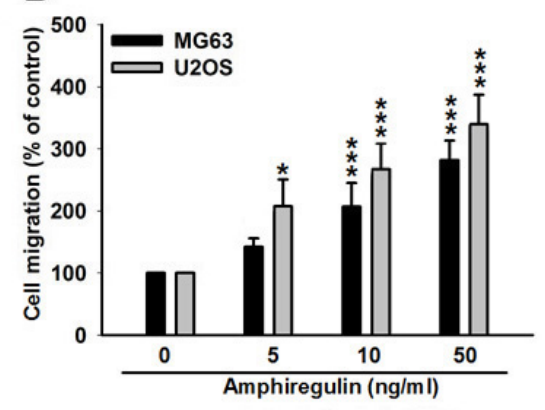

E
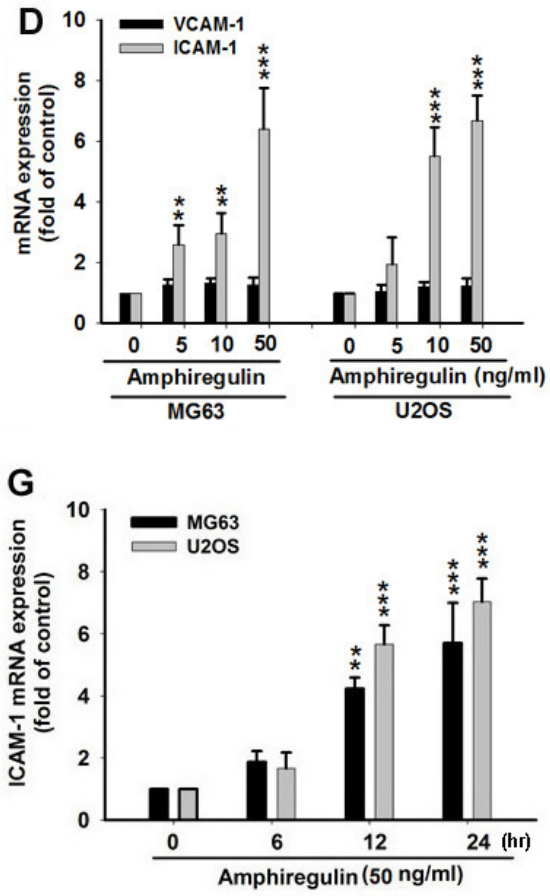

H

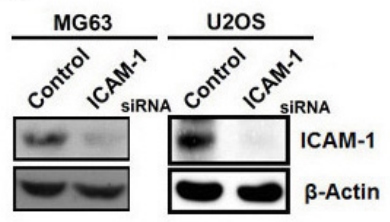

C

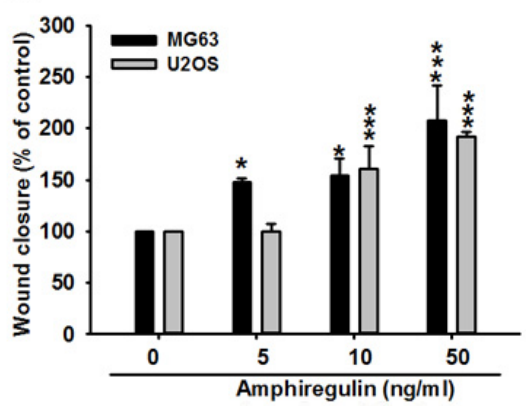

$\mathbf{F}$



U2OS

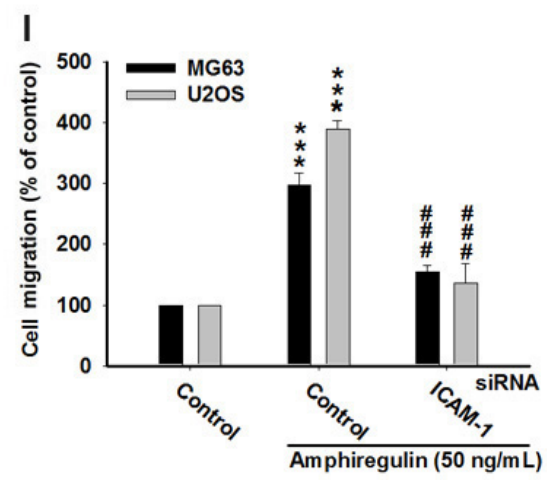

Figure 1: ICAM-1 regulates the AREG-induced cell migration of osteosarcoma. A. Total protein was extracted from hFOB 1.19, MG63, and U2OS cells and the levels of AREG and ICAM-1 were examined by western blot analysis. B-C. Cells were incubated with different concentrations of AREG for $24 \mathrm{hr}$ and in vitro migration was measured using the Transwell assay and Wound-healing migration assay. D-G. Cells were incubated with various concentrations of AREG for $24 \mathrm{hr}$ or with $50 \mathrm{ng} / \mathrm{mL}$ AREG for 6, $12 \mathrm{or} 24 \mathrm{hr}$. The mRNA level or protein expression of ICAM-1 was then measured by qPCR or Western blotting respectively. H. Cells were transfected with ICAM1 or negative control siRNA (Control) for $24 \mathrm{hr}$, I. followed by treatment with AREG for $24 \mathrm{hr}$. Cell migration was then analyzed using the Transwell assay. All bars represent the mean \pm SEM. The asterisks indicate that the data are significantly different from the control without AREG treatment. *represents $P<0.05$, **represents $P<0.01$, ${ }^{* * *}$ represents $P<0.001$, as compared to respective control by using one-way ANOVA followed by Bonferroni's post-hoc test. \#\#\#represents $P<0.01$, comparisons to the control treated with AREG by using one-way ANOVA followed by Bonferroni's post-hoc test.

Our study demonstrates that higher expression of AREG promotes the migration of osteosarcoma cells and that AREG supplementation can further enhance migration. Because recent studies have also indicated that ICAM-1 plays a key role in cancer cell migration and invasion [47, 48], ICAM-1 may be involved in the AREG-induced migration. Therefore, we measured the expression levels of ICAM-1 mRNA and protein in AREG treated osteosarcoma cells and determined that these levels were increased by AREG treatment in a dose-dependent and time-dependent pattern (Figure 1D-1G). However, AREG treatment had no effect on the mRNA or protein level of VCAM-1 (vascular cell adhesion molecules) (Figure 1D-1G), though these molecules have also been shown to influence cancer invasion [49]. We also found that the expression of ICAM-1 was elevated in osteosarcoma cells (Figure 1A). To further confirm the role of ICAM-1 in the AREG-induced migration, the MG63 and U2OS cells were transfected with ICAM-1 small interfering RNA (siRNA) for $24 \mathrm{hr}$. 
Transfection of ICAM-1 siRNA reduced the protein level of ICAM-1 (Figure 1H), also in addition to fully suppressing the AREG-induced cell migration (Figure 1I). These observations imply that enhanced ICAM-1 expression contributes to the AREG-induced cancer cell migration and ICAM-1 works downstream of AREG to regulate the cell migration of osteosarcoma.

\section{AREG mediates the cancer cell migration of osteosarcoma through EGFR}

Several studies have reported that AREG specifically binds to the EGFR, which affects several cellular functions such as cell proliferation, differentiation and migration $[41,50,51]$. In addition, the EGFR plays a critical role in cancer cell migration and invasion [52]. To test whether AREG increased the cell migration of osteosarcoma through EGFR, we reduced the EGFR expression by transfecting EGFR siRNA (Figure 2A) and found that EGFR siRNA inhibited the AREG-induced cancer cell migration and inhibited the AREG-induced ICAM-1 upregulation of the mRNA level (Figure 2B-2C). Furthermore, treatment with PD158780 and BIBX1382, two commonly used EGFR tyrosine kinase inhibitors that can block the autophosphorylation (activation) of EGFR $[53,54]$, had the same suppressive effects of EGFR SiRNA on the AREG-enhanced migration and ICAM-1 upregulation, indicating that EGFR activation is required for AREG-mediated migration (Figure 2D-2F). Because activating the EGFR leads to the autophosphorylation of its tyrosine residues [55-57], we examined the level of the phosphorylated EGFR at tyrosine 1068 and 992 after treatment. We observed that AREG treatment increased the level of phosphorylated EGFR (Figure 2G). These results indicated that AREG and EGFR interacted to regulate the migration of osteosarcoma and the expression level of ICAM-1.

\section{PI3K/Akt signaling pathway is involved in AREG-mediated ICAM-1 up-regulation and cell migration of osteosarcoma cells}

Previous studies have demonstrated that EGFR overexpression promotes cancer cell survival, proliferation, migration, and invasion [58]. The promotion mechanism is associated with the PI3K/Akt signaling pathway that
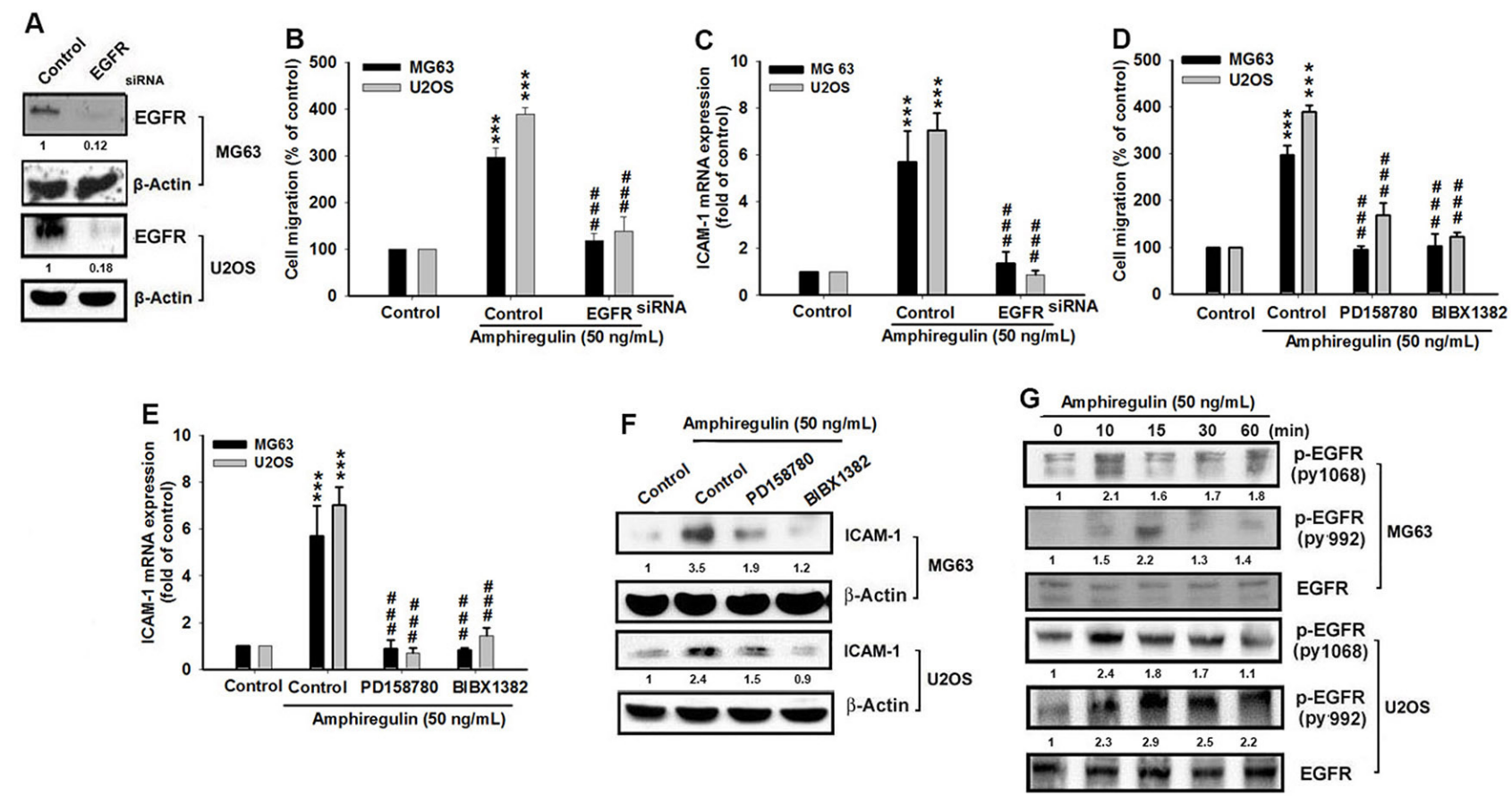

Figure 2: EGFR is involved in AREG-mediated migration of human osteosarcoma cells. A. Cells were transfected with EGFR siRNA or negative control siRNA (Control) for $24 \mathrm{hr}$. The EGFR expression was examined by western blotting. B-C. After transfection of siRNA, cells were treated with AREG for $24 \mathrm{hr}$. Cell migration was analyzed using the Transwell assay and the mRNA level of ICAM-1 was measured. D-F. Cells were pretreated for 30 min with PD158780 $(5 \mu \mathrm{M})$ or BIBX1382 $(10 \mu \mathrm{M})$ followed by the stimulation with AREG for $24 \mathrm{hr}$. Both EGFR tyrosine kinase inhibitors can suppress the AREG-induced cell migration and the AREGenhanced expression of ICAM-1 in mRNA or protein level. G. Cells were incubated with AREG for indicated time intervals and EGFR phosphorylation at Y992 or Y1068 was detected with specific antibodies. All bars represent the mean \pm SEM. The asterisks indicate that the data are significantly different from the control without AREG treatment. ***represents $P<0.001$, as compared to respective control by using one-way ANOVA followed by Bonferroni's post-hoc test. \#\#\#represents $P<0.01$, comparisons to the control treated with AREG by using one-way ANOVA followed by Bonferroni's post-hoc test. 
stimulates cell survival and suppresses cell apoptosis $[59,60]$. Because AREG supplementation can increase EGFR activity, which consequently enhances osteosarcoma cell migration, we speculated whether the PI3K/Akt signaling pathway mediates the AREG-induced cell migration. To test this, we first treated osteosarcoma cells with PI3K inhibitors, Ly294002 and Wortmannin [61]. We found that treatment with PI3K inhibitors suppressed the AREG-induced migration and ICAM-1 expression in mRNA and protein level (Figure 3A-3C). The same suppressive effect was observed in the dominant-negative mutant of PI3K p85-transfected cells (Figure 3D-3E), indicating that PI3K works downstream of AREG to affect the migration of osteosarcoma and to regulate the expression of ICAM-1. To further explore whether AREG actives PI3K, we measured the level of phosphorylated $\mathrm{p} 85$, which has been associated with PI3K activity [62]. We observed that AREG treatment led to an increase in the phosphorylation of p85 (Figure 3D). These reading suggest that AREG treatment increases the activation of the PI3K pathway through EGFR signaling. Therefore, we decreased EGFR signaling by treatment with EGFR inhibitors, PD158780 or BIBX1382, and measured the level of phosphorylated p85. Both inhibitors were found to suppress the AREG-induced PI3K activation (Figure 3E).

To further understand whether the downstream target of the PI3K signaling pathway, Akt can also be activated by AREG treatment, we determined the level of phosphorylated Akt at Ser473, which was used in a previous study as an indicator of Akt activity [63].
We determined that AREG treatment increased the phosphorylation of Akt at Ser473 (Figure 4A). Moreover, like its upstream regulator, $\mathrm{PI} 3 \mathrm{~K}$, Akt regulates the AREGinduced cancer cell migration of osteosarcoma and the expression of ICAM-1 at treatment with an Akt inhibitor (Akti) [61], can inhibit the AREG-induced migration and ICAM-1 up-regulation (Figure 4B-4D). In addition, we observed the same suppressive effect in the dominantnegative mutant of Akt-transfected cells (Figure 4E-4F). Overall these results imply that AREG and EGFR act through the PI3K/Akt-dependent signaling pathway to enhance ICAM-1 expression and cell migration in human osteosarcoma cells.

\section{PI3K/Akt mediates AREG-induced ICAM-1 expression via its downstream IKK/ NF- $\kappa B$ signaling pathway}

Nuclear factor $-\kappa \mathrm{B}(\mathrm{NF}-\kappa \mathrm{B})$ is a major transcription factor that regulates several genes involved in cancer cell migration and invasion [64]. The activation of the factor requires $\mathrm{I} \kappa \mathrm{B}$ kinase (IKK), a substrate of $\mathrm{Akt}$; thus, the activation of Akt stimulates NF- $\kappa \mathrm{B}$ activity. To understand whether NF- $\kappa \mathrm{B}$ and IKK are involved in AREG-induced cancer cell migration, we treated osteosarcoma cells with a NF- $\kappa \mathrm{B}$ inhibitor(PDTC) and an IKK inhibitor (TPCK). We found that both inhibitors suppressed the AREGinduced cancer cell migration and ICAM-1 expression in mRNA and protein levels (Figure 5A-5C). Furthermore,
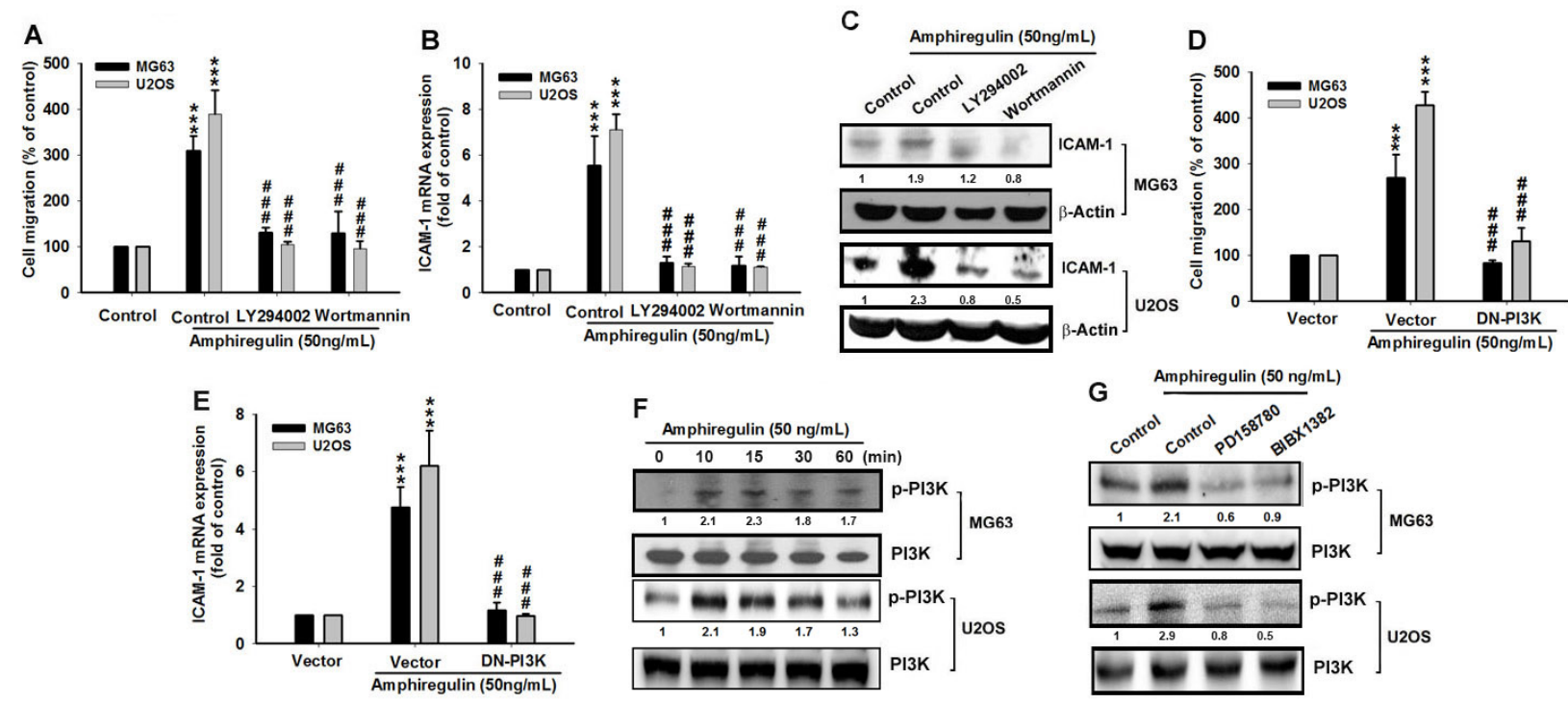

Figure 3: PI3K signaling regulates the AREG response in human osteosarcoma. A-C. Cells were pretreated with $0.1 \%$ DMSO as control, LY294002 $(10 \mu \mathrm{M})$ or Wortmannin $(1 \mu \mathrm{M})$ for 30 min followed by the stimulation with AREG for $24 \mathrm{hr}$. Cell migration and ICAM-1 expression level were examined. D-E. As PI3K inhibitors, the dominant-negative mutation of PI3K (DN-PI3K) had the same suppressive effect on both the AREG-induced cell migration and ICAM-1 up-regulation. Results are shown as the mean \pm SEM. The asterisks indicate $t$-test comparisons to the control without AREG treatment. ***represents $P<0.001$. \#\#represents $P<0.01$ for one-way ANOVA comparisons as indicated. F. Cells were treated with AREG $(50 \mathrm{ng} / \mathrm{ml})$ for the indicated times and PI3K p85 phosphorylation (p-PI3K) was detected by specific antibody. G. Cells were pretreated with $0.1 \%$ DMSO as control, PD158780 (5 $\mu$ M) or BIBX1382 $(10 \mu \mathrm{M})$ for $1 \mathrm{hr}$ followed by stimulation with AREG for $10 \mathrm{~min}$ and then the level of phosphorylated p85 (p-PI3K) was examined. 
A

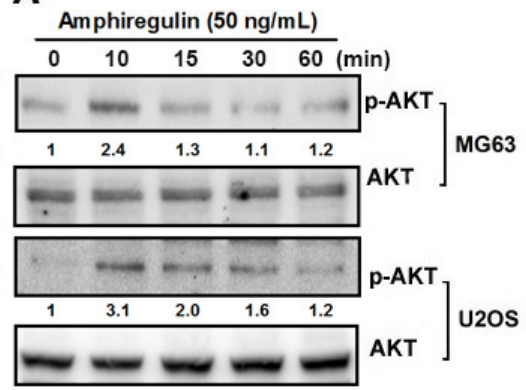

D Amphiregulin $(50 \mathrm{ng} / \mathrm{mL})$

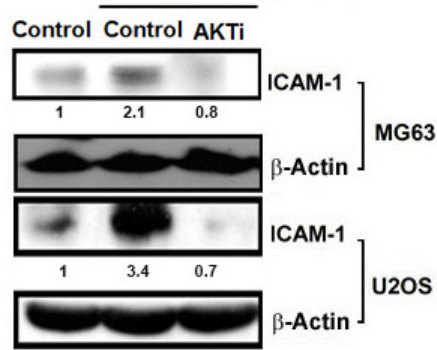

B


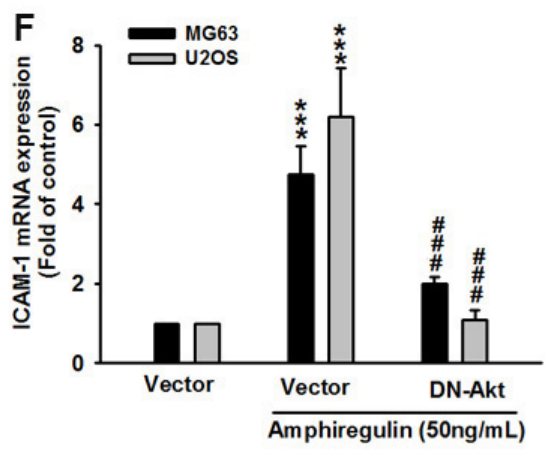

Figure 4: The involvement of Akt in AREG-mediated migration of human osteosarcoma cells. A. Cells were treated with AREG $(50 \mathrm{ng} / \mathrm{ml})$ for the indicated times. The levels of Akt and its phosphorylated form, p-AKT, were determined by Western blotting. B-D. Cells were pretreated for $30 \mathrm{~min}$ with the Akt inhibitor (Akti) $(1 \mu \mathrm{M})$ for $1 \mathrm{hr}$ followed by treatment with AREG for $24 \mathrm{hr}$. The cell migration and ICAM-1 expression were measured. E-F. Cells were transfected with dominant negative Akt gene (DN-AKT) for $24 \mathrm{hr}$ followed by treatment with AREG for $24 \mathrm{hr}$. The cell migration and ICAM-1 expression were measured. Data are shown as the mean $\pm \mathrm{SEM}$. The asterisks represent $p$ values obtained by $t$-test comparing to what was observed with $0.1 \%$ DMSO only (Control). $* * *$ represents $P<0.001$. \#\#represents $P<0.01$ for one-way ANOVA comparisons as indicated. \#\#\#represents $P<0.001$.

the expression of dominant-negative mutant of IKK $\alpha$ or IKK $\beta$ mimicked the effect of the IKK inhibitor to constrain the AREG-induced cell migration and ICAM-1 mRNA expression (Figure 5A-5B). We further investigated whether AREG activates NF- $\mathrm{KB}$ signaling through the PI3K/Akt pathway. We first observed that AREG stimulation increased the phosphorylation of

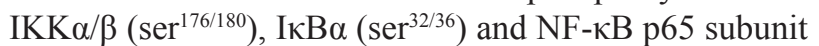
$\left(\operatorname{ser}^{536}\right)$ in a time-depend pattern (Figure 5D); these kinase, are all known to contribute to NF- $\mathrm{KB}$ activation [65]. Moreover, PI3K inhibitors (Ly294002, or Wortmannin) and pan-Akt inhibitor (Akti) reduced the AREGinduced phosphorylation of IKK $\alpha / \beta$, I $\kappa B$ and NF- $\kappa B$ p65 (Figure 5E), indicating that the PI3K/Akt pathway modulates the activation of NF- $\mathrm{\kappa B}$ in response to AREG stimulation. Notably a decrease of phosphorylated IкB $\alpha$ $\left(\operatorname{ser}^{32 / 36}\right)$ in the MG63 cell was observed at the $60 \mathrm{~min}$ point compared with that at the $30 \mathrm{~min}$ point (Figure 5D), possibly because of phosphorylation at $\operatorname{ser}^{32 / 36}$ resulting in its own subsequent ubiquitination and degradation [66].

The data presented in the preceding paragraphs suggest that AREG activates the transcription factor NF- $\kappa \mathrm{B}$ which in turn upregulates ICAM-1 expression. Therefore, we can speculate that the NF- $\mathrm{KB}$ p65 subunit may bind to the NF- $\mathrm{kB}$ element on the ICAM-1 promoter after AREG stimulation. To test this, we assessed in vivo recruitment of p65 to the ICAM-1 promoter (-346 to -24$)$ by conducting a chromatin immunoprecipitation assay [15]. We determined that AREG treatment enhanced the association of p65 with the ICAM-1 promoter. However, the PI3K inhibitors (Ly294002 or Wortmannin) and Akt inhibitor (Akti) reduced the AREG-induced binding of p65 to the NF- $\mathrm{KB}$ element (Figure $5 \mathrm{~F}$ ). This finding is consistent with those of previous studies, confirming that AREG activates NF- $\mathrm{kB}$ signaling to modulate ICAM-1 expression through the PI3K/Akt pathway. Next, we examined the level of the NF-KB-driven transcription by transfecting cells with the NF-kB-luciferase reporter, which enabled us to measure the NF- $\kappa B$ activity. We discovered that NF- $\kappa B$ activity markedly increased upon AREG stimulation, whereas treatments of PD158780, BIBX1382, LY294002, Wortmannin, Akti, PDTC and TPCK blocked this response (Figure 5G). The dominant-negative mutants of PI3K, Akt, IKK $\alpha$ and IKK $\beta$ also strongly impaired AREG-induced $\mathrm{NF}-\kappa \mathrm{B}$ activity (Figure $5 \mathrm{H}$ ). These results confirm that the PI3K/Akt pathway mediates the response of osteosarcoma cells to AREG, and promotes IKK/NF- $\kappa \mathrm{B}$ signaling to induce the expression of ICAM-1. 




D

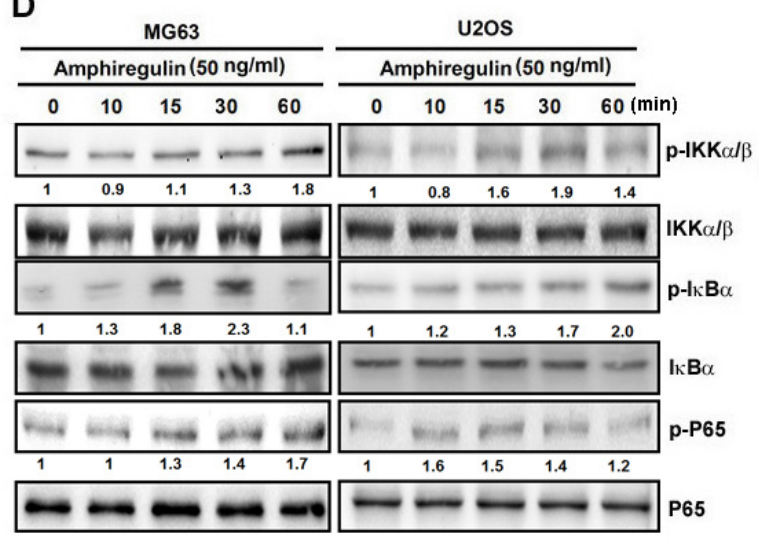

C
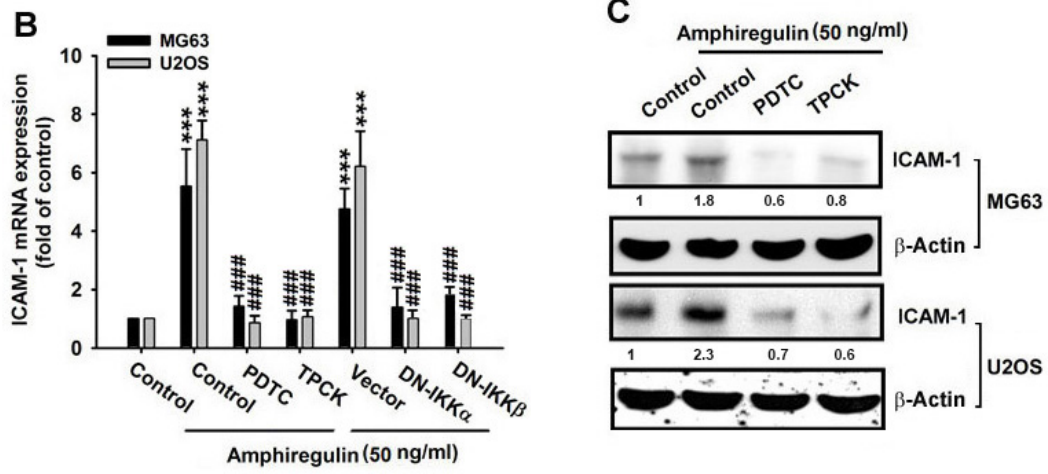

$\mathbf{E}$

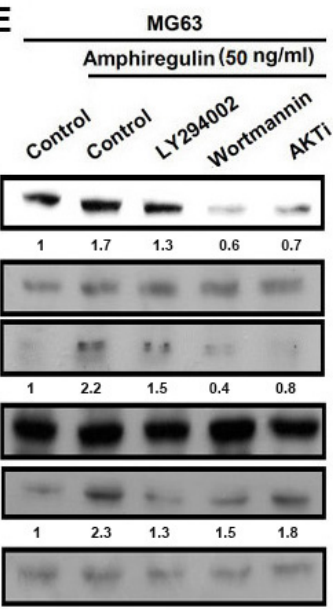

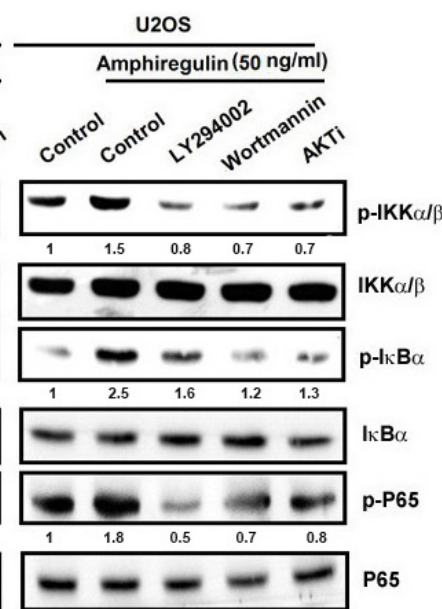

$\mathbf{F}$

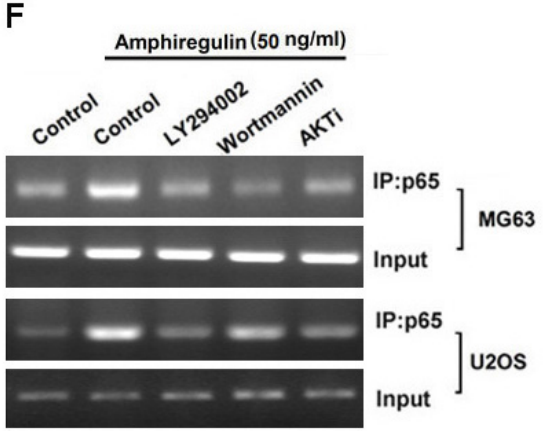

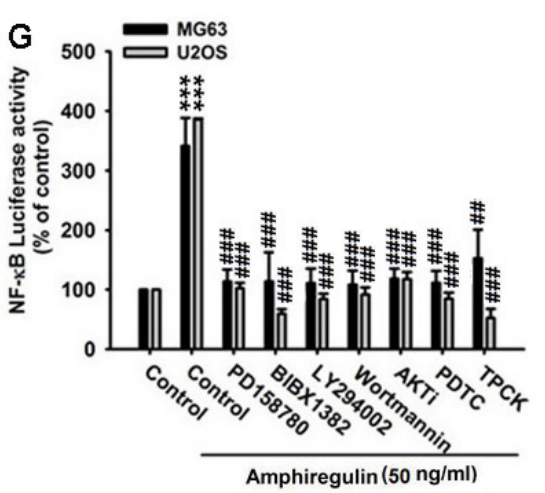

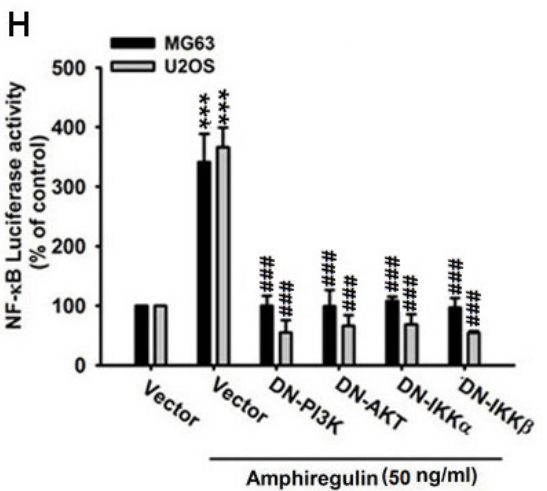

Figure 5: NF-кB mediates the response of human osteosarcoma cells to AREG stimulation. A-C. Cells were pretreated with $0.1 \%$ DMSO as control, PDTC $(10 \mu \mathrm{M})$ or TPCK $(10 \mu \mathrm{M})$ for 30 min or were transfected with dominant negative gene of IKK $\alpha$ or IKK $\beta$ for $24 \mathrm{hr}$, followed by AREG treatment for $24 \mathrm{hr}$. The cell migration and ICAM-1 expression were then measured. D. Cells were treated with AREG $(50 \mathrm{ng} / \mathrm{ml})$ for the indicated times and the levels of phosphorylated IKK $\alpha / \beta, \mathrm{I} \kappa \mathrm{B} \alpha$, and p65 were examined by Western blotting. E. Cells were pretreated with $0.1 \%$ DMSO as control, LY294002 $(10 \mu \mathrm{M})$, Wortmannin $(1 \mu \mathrm{M})$ or AKTi $(1 \mu \mathrm{M})$ for $1 \mathrm{hr}$ followed by stimulation with AREG for $30 \mathrm{~min}$. The level of IKK $\alpha / \beta$, I $\kappa \mathrm{B} \alpha$, or $\mathrm{p} 65$ and their phosphorylated forms were determined by Western blotting. F. Cells were pretreated with $0.1 \%$ DMSO as control, LY294002 $(10 \mu \mathrm{M})$, Wortmannin $(1 \mu \mathrm{M})$ or AKTi $(1 \mu \mathrm{M})$ for $30 \mathrm{~min}$, followed by AREG treatment $(50 \mathrm{ng} / \mathrm{ml})$ for $120 \mathrm{~min}$. Chromatin immunoprecipitation was performed with antibody against p65. One percent of immunoprecipitated chromatin was assayed to verify equal loading (Input). G-H. Osteosarcoma cells were transfected with a plasmid harboring the NF- $\mathrm{KB}$ luciferase reporter for $24 \mathrm{hr}$ and then the stable cell lines were treated with indicated inhibitors for $30 \mathrm{~min}$ or was transfected with different dominant negative genes for $24 \mathrm{hr}$. Luciferase activity was measured after AREG stimulation for $24 \mathrm{hr}$. Data are shown as the mean \pm SEM. The asterisks indicate $t$-test comparisons to the control of $0.1 \%$ DMSO treatment or to cells transfected with the empty vector (Vector). ***represents $P<0.001$. \#represents $P<0.05$ for one-way ANOVA comparisons as indicated. \#\#represents $P<0.01$. \#\#\#represents $P<0.001$. 


\section{Knockdown of AREG expression inhibits cell migration in a mouse model of osteosarcoma}

According to the results described thus far, we can hypothesize that elevated levels of AREG in osteosarcoma stimulate cancer cell migration by promoting ICAM-1 expression. To test this hypothesis, we reduced the AREG level in the MG63 cells by stably expressing human AREG shRNA. Following puromycin $(10 \mu \mathrm{g} / \mathrm{mL})$ selection, we isolated four individual shRNA clones and compared them with the harboring only the empty vector; we observed that the expression levels decreased in all clones at dissimilar degrees (Figure 6A). We also found that the degree of change in the AREG level is associated with the drop in the ICAM-1 expression and in cell migration rate (Figure 6A-6B). However, the knockdown of AREG did not alter the cell proliferation rate (Figure $6 \mathrm{C}$ ). We examined the effect of AREG on the osteosarcoma cell migration in vivo by injecting MG63 cells $\left(5 \times 10^{6}\right)$ into the tail veins of mice. The mice were sacrificed after 28 days with developed osteosarcoma lung metastases. To investigate whether AREG expression would influence tumor metastasis in vivo, we monitored the metastatic potential of the MG63 cells stably expressing control shRNA or AREG shRNA in mouse models of lung metastasis. On day 28 after injection, the tumor size in the lung was significantly reduced when AREG expression was knocked down (Figure 6D). Next, we applied histological analyses to lung tissues from mice by using hematoxylin and eosin (H\&E) staining. The lung tissues from mice injected with AREG knockdown MG63 cells exhibited a nearly normal structure or dramatically reduced degrees of lung metastatic nodules. However, lung tissues from the control group mice were heavily infiltrated (Figure 6E). To further investigate the metastatic potential of osteosarcoma defined by counting the numbers of metastatic nodules, the mean number was significantly decreased in the mice injected with AREG shRNA expressing cells (Figure 6F), strongly indicating that AREG promotes cell metastasis and tumor progression of osteosarcoma in vivo.

\section{DISCUSSION}

Although osteosarcoma is an uncommon tumor, it is the primary malignant bone tumor prevalent in children and adolescents. The survival rate of osteosarcoma has
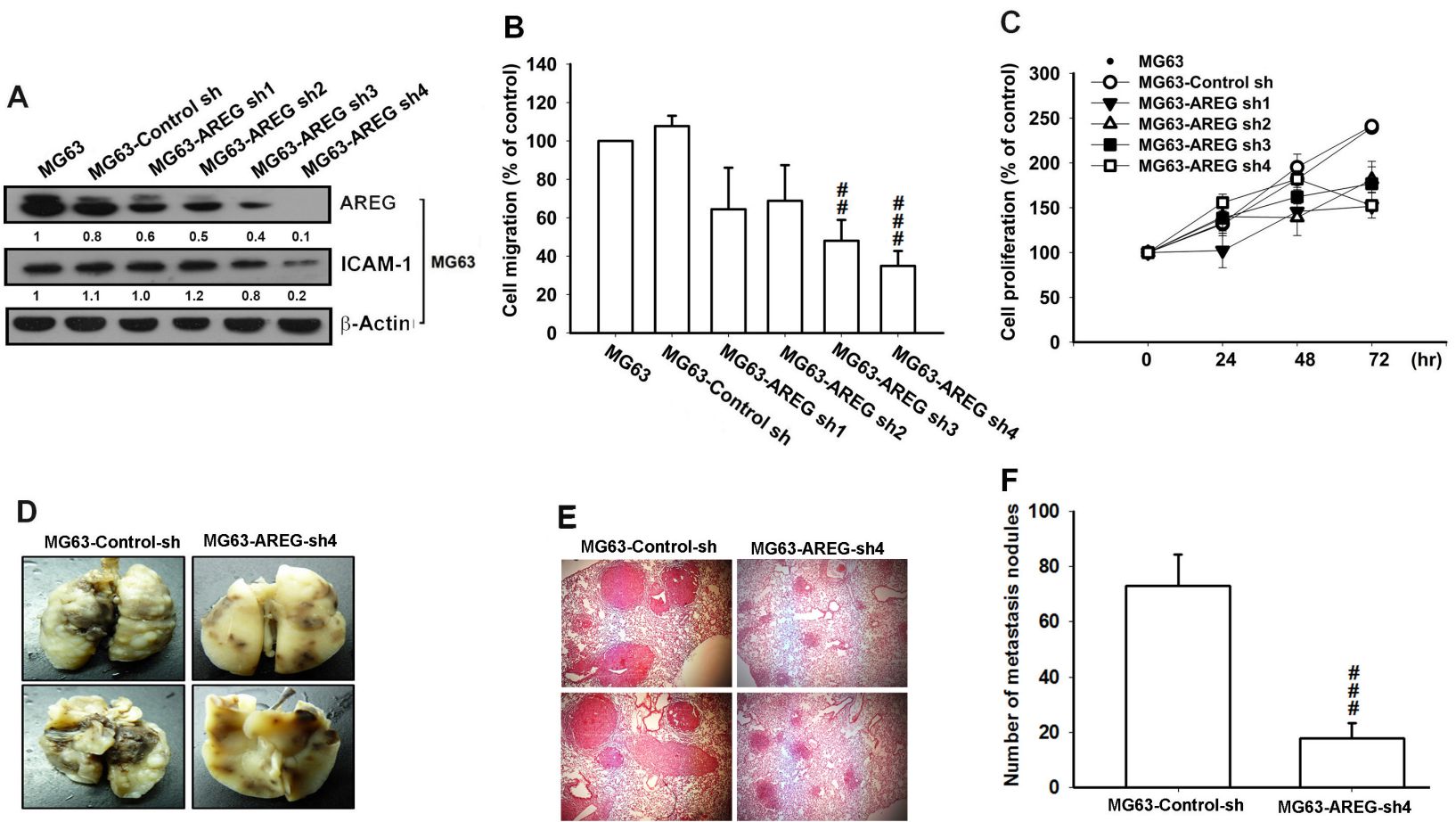

Figure 6: Knockdown of AREG inhibited the migratory ability of osteosarcoma cells. A. Treating MG63 cells with shRNA against AREG decreased the protein level of AREG as well as that of ICAM-1. B. shRNA knockdown of AREG decreased the in vitro migration activity of osteosarcoma cells, $\mathbf{C}$. but it had no effect on the their cell proliferation rate. D. To induce pulmonary metastases, MG63 cells were injected into the mouse tail vein and those mice were sacrificed after 28 days later with developed lung metastatic nodules. Compared to the control mice, there are fewer and smaller tumors which were seen on the lungs of mice injected with osteosarcoma cells transfected with shRNA against AREG. E. H\&E staining of lung metastatic nodules of MG63 injected mice. F. The lungs of MG63 injected mice were removed and inflated with $10 \%$ paraformaldehyde fixative. The number of lung metastatic nodules was counted under a dissecting microscope. Results are shown as mean \pm SEM. \#\#represents $P<0.01$ fort-test comparisons to cells harboring only the empty vector as control. \#\#\#represents $P<0.001$. 
improved immensely with the inducetion of chemotherapy. Nonetheless, despite achieving local tumor control, $80 \%$ of patients with osteosarcoma develop metastatic disease. ICAM-1 is a cell surface transmembrane glycoprotein, which is associated with several inflammatory and immune responses. ICAM-1 is an adhesion molecule that is involved in cancer metastasis. The effect of AREG on tumor migration has been explained previously. The overexpression of growth factor receptors of tumor cells, which enhance the cell's downstream signaling, increase their proliferation rates and metastatic potential in addition to promoting angiogenesis. Willmarth and Ethier reported that MCF10A cells overexpressing AREG exhibited increased cell motility and invasion capabilities and that AREG up-regulated the expression of several genes associated with cell adhesion and motility [33]. Moreover studies have reported that most malignant breast cancer cell lines express a high level of AREG, suggesting that AREG may promote metastasis $[67,68]$. In addition to our findings, several studies have demonstrated that AREG activates EGFR signaling to synthesize, secrete, and activate proteins involved in invasion and metastasis such as urokinase-type plasminogen activator (uPA), matrix metalloproteinase 9 (MMP-9), and extracellular matrix metalloproteinase inducer (EMMPRIN) [69-71].

Immunohistochemistry (IHC) applied for clinical specimens derived from patients with osteosarcoma revealed that the AREG expression level correlated with tumor stage in osteosarcoma. Using cellular-level experiments, we also demonstrate that AREG promotes ICAM-1 expression and migration in osteosarcoma. In addition, AREG promotes ICAM-1 expression and migration via EGFR signaling through the PI3K/Akt/ $\mathrm{NF}-\kappa \mathrm{B}$ pathways. Therefore, AREG may be a new molecular therapeutic target for reduction of metastasis in osteosarcoma.

Increasing evidence suggests that EGFR pathways are involved in the progression of cancer of the bone, soft tissue, breast, and lungs [72, 73]. EGFR expression is linked to poor prognosis in numerous cancers. In addition, EGFR inhibitor gefitinib (Iressa) is successful for treating of non-small cell lung cancer [74]. EGFR expression has even been proven to predict poor outcome in osteosarcoma $[75,76]$. Here, we report that treatment with an EGFR inhibitors or siRNA antagonized AREG-induced ICAM-1 expression and cell migration. Incubation of osteosarcoma cells with AREG promotes the level of phosphorylated EGFR at tyrosine 1068 and 992. These results indicate that AREG and EGFR interact together to regulate the migration of osteosarcoma and the expression level of http://ICAM-1.In this study, we conducted a detailed analysis of AREG association with osteosarcoma metastasis. In summary, we determined that: 1) two osteosarcoma cell lines expressed high levels of AREG; 2) exogenous AREG further enhanced cell migration of osteosarcoma cells and the expression of ICAM-1; 3) these AREG-induced enhancements were suppressed by siRNA knockdown of ICAM-1 or EGFR, with the same suppressive effect mimicked by treating with inhibitors of EGFR, PI3K, Akt, NF- $\kappa \mathrm{B}$, and IKK or by expressing dominant-negative mutant forms of PI3K, Akt, IKK $\alpha$, and IKK $\beta ; 4)$ exogenous AREG also increased the activities of EGFR, PI3K, Akt, and NF- $\mathrm{BB}$ by enhancing their phosphorylated levels; 5) the AREG increased-activity of NF- $\kappa \mathrm{B}$ can be abolished by treatment with inhibitors of EGFR, PI3K, Akt, NF- $\mathrm{BB}$, and IKK, or by expressing dominant-negative mutant forms of PI3K, Akt, IKK $\alpha$, and IKK $\beta$; 6) AREG stimulation promoted the association of $\mathrm{NF}-\kappa \mathrm{B}$ to the ICAM-1 promoter, which then up-regulated the ICAM-1 expression; 7) osteosarcoma cells overexpressing AREG shRNA exhibited less motility, and mice injected with these cells demonstreated fewer and smaller metastatic nodules.

In summary, our findings suggested that AREG promoted cancer cell motility of osteosarcoma and up-regulated the expression of ICAM-1 through the EGFR/PI3K/Akt/NF-кB signaling pathway (Figure 7). Genetic silencing through transfection with siRNA of EGFR or ICAM-1 and pretreatment with inhibitors of EGFR, PI3K, Akt, NF- $\kappa$ B and IKK abrogated the AREGenhanced ICAM-1 expression and cancer cell migration. However, exogenous AREG enhanced cell migration and ICAM-1 expression. Our findings indicated that AREG plays a critical role in tumor invasion and tumorigenesis of bone sarcomas. Indeed, studies have reported that AREG stimulates directional migration and invasion of human cancer cells [43, 77]. Moreover, we observed that overexpression of AREG shRNA inhibited cancer migratory ability by approximately 60\% (Figure 6B). Overall, we validated that the expression of AREG is associated with osteosarcoma metastasis, signifying that AREG is a novel marker for cancer progression and metastasis of bone sarcomas.

\section{MATERIALS AND METHODS}

\section{Materials}

Protein A/G beads, anti-mouse and anti-rabbit IgG conjugated horseradish peroxidase and polyclonal antibodies that are specific for AREG, , VCAM-1, EGFR, PI3K, Akt, IKK $\alpha / \beta$, I $\mathrm{B}, \mathrm{p} 65$ and $\beta$-Actin were purchased from Santa Cruz Biotechnology (Santa Cruz, CA, USA). Polyclonal antibodies that are specific for EGFR phosphorylated at $\mathrm{PY}^{1068}$ or at $\mathrm{PY}{ }^{992}$, PI3K phosphorylated at $\mathrm{Tyr}^{458 / 199}$, Akt phosphorylated at $\mathrm{Ser}^{473}$, IKK $\alpha / \beta$ phosphorylated at $\operatorname{Ser}^{176 / 180}$, I $\kappa \mathrm{B} \alpha$ phosphorylated at $\mathrm{Ser}^{32 / 36}$, p65 phosphorylated at $\mathrm{Ser}^{536}$ and ICAM-1 were purchased from Cell Signaling and Neuroscience (Danvers, MA, USA). PD158780, BIBX1382, PDTC 


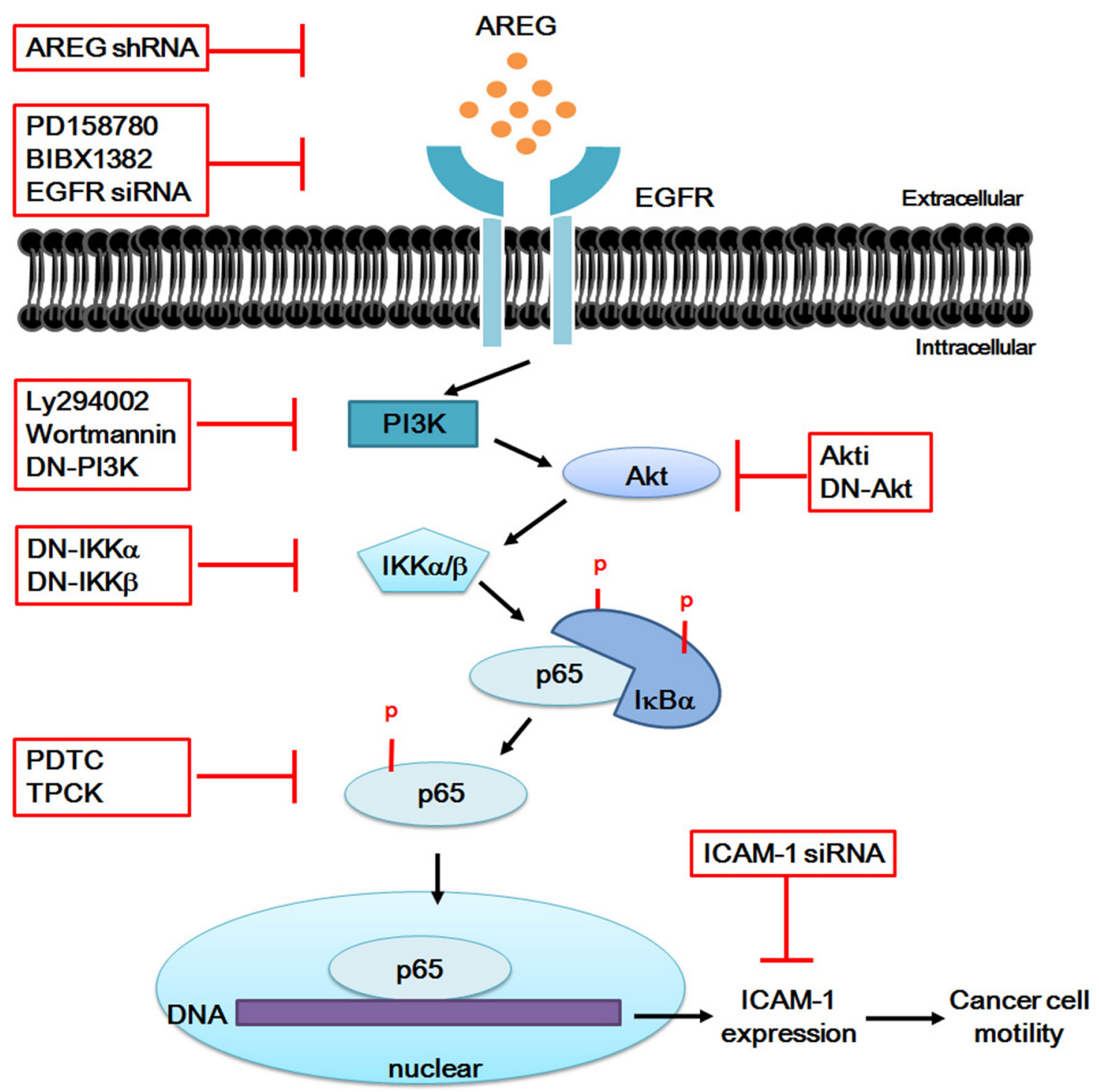

Figure 7: Schematic diagram illustrating the proposed signaling pathway involved in AREG-induced ICAM-1 expression in human osteosarcoma cells. AREG induces the activation of NF- $\mathrm{kB}$ p65 through EGFR/PI3K/Akt signaling pathway. Activated NF-kB p65 was recruited to the promoter region of ICAM-1 leading to an increased expression of ICAM-1. Therefore, blockade of these pathways by treatments of different inhibitors or RNAi knockdown can reduce ICAM-1 expression and then decrease the tumor cell motility of osteosarcoma cells. See "Discussion" for further explanation.

(Pyrrolidine-dithiocarbamate), TPCK (L-1-tosylamido2-phenylenylethyl chloromethyl ketone), LY294002, Wortmannin, and AKT inhibitor (1L-6-hydroxymethylchiro-inositol-2-( $R$-2-2-O-methyl-3-O-octadecylcarbonate) were purchased from Calbiochem (San Diego, CA, USA). The recombinant human AREG was purchased from PeproTech (Rocky Hill, NJ, USA). The NF- $\mathrm{kB}$ luciferase plasmid was purchased from Stratagene (La Jolla, CA, USA). The p85 and Akt (Akt K179A) dominant-negative mutants were gifts from Dr. Wen-Mei Fu (National Taiwan University, Taipei, Taiwan). The IKK $\alpha$ (IKK $\alpha-\mathrm{KM})$ and $\operatorname{IKK} \beta(\mathrm{IKK} \beta-\mathrm{KM})$ dominant-negative mutants were gifts from Dr. H. Nakano (Juntendo University, Tokyo, Japan). The pSV- $\beta$-galactosidase vector and the luciferase assay kit were purchased from Promega (Madison, MA, USA). Unless otherwise specified, all other chemicals were obtained from Sigma-Aldrich (St. Louis, MO, USA).

\section{Cell culture}

The human osteosarcoma cell lines (U2OS and MG63) and human fetal osteoblastic cell line (hFOB 1.19) were purchased from the American Type Cell Culture Collection (Manassas, VA, USA). Cells were maintained as previously described [78-80]. All experiments with hFOB 1.19 cells were carried out at the permissive temperature of $33.5^{\circ} \mathrm{C}$ for the expression of the large $\mathrm{T}$ antigen. 


\section{Cell proliferation assay}

Cell proliferation assay was performed using MTT (3-(4, 5-dimethylthiazol-2-yl)-2, 5-diphenyl tetrazolium bromide) (Sigma-Aldrich, St. Louis, MO, USA). Cells were seeded in a 96 well plate $\left(1 \times 10^{4}\right.$ cells/well $)$. After $24 \mathrm{hr}$, the cells were subjected to the indicated treatments for $24 \mathrm{hr}$. Cell proliferation was measured by adding $10 \mu \mathrm{l}$ of MTT stock solution $(5 \mathrm{mg} / \mathrm{mL})$ to each well, and the plate was incubated at $37^{\circ} \mathrm{C}$ for $2 \mathrm{hr}$. To solubilize formazan, dimethyl sulfoxide (DMSO) was added, and the plate was incubated in a humidified chamber at $37^{\circ} \mathrm{C}$ for $30 \mathrm{~min}$. The cell proliferation was then determined by measuring the absorbance at $570 \mathrm{~nm}$ which can be read using a microplate spectrophotometer (PowerWave X340, BioTek Instruments, Winooski, VT, USA).

\section{Migration assay}

Using Transwell ${ }^{\circledR}$, the migration assay was measured according to a previously described method that was modified as following [81]. Before performing the migration assay, cells were treated for $30 \mathrm{~min}$ with different concentrations of inhibitors (LY294002, Wortmannin, Akt inhibitor, PDTC or TPCK) or their solvent control ( $0.1 \%$ dimethyl sulfoxide). Approximately $1 \times 10^{4}$ cells in $200 \mu \mathrm{l}$ of serum-free medium were placed in the upper chamber and $300 \mu \mathrm{l}$ of the same medium containing different concentrations of AREG were placed in the lower chamber. The cells were incubated at $37^{\circ} \mathrm{C}$ with $5 \% \mathrm{CO}_{2}$ for $24 \mathrm{hr}$, and then were fixed with $3.7 \%$ formaldehyde for $15 \mathrm{~min}$ and stained with $0.05 \%$ crystal violet in phosphatebuffered saline (PBS) for $15 \mathrm{~min}$. Cells were counted under an OLYMPUS IX70 inverted phase-contrast microscope. Each experiment was performed in triplicate and was repeated at least three times. The number of migrating cells in each experiment was adjusted by the cell viability assay to correct for proliferation effect of AREG treatment (corrected migrating cell number $=$ counted migrating cell number/ percentage of viable cells).

\section{Wound-healing migration assay and western blot analysis}

Wound-healing migration assay and western blot analysis were performed as previously described with following modifications [46, 82]. After transfer, the blots were blocked with 5\% BSA at room temperature for $1 \mathrm{hr}$. and then probed with different rabbit antihuman antibodies that are against $\mathrm{PI} 3 \mathrm{~K}, \mathrm{Akt}, \mathrm{IKK} \alpha / \beta$, I $\mathrm{B}, \mathrm{p} 65$, EGFR, ICAM-1 (1:1000) at room temperature for $1 \mathrm{hr}$. The blots were visualized by enhanced chemiluminescence which can be detected by FUJI Super RX-N X-RAY film (Fujifilm Corporation, Tokyo, Japan). Quantitative data were obtained using a computing densitometer and Image Quant software (Molecular Dynamics, Sunnyvale, CA, USA).

\section{Quantitative real time PCR}

Total RNA was extracted from the cells using a TRIzol kit (MDBio Inc., Taipei, Taiwan) and then $2 \mu \mathrm{g}$ RNA was used for synthesis of complementary DNA (cDNA) by reverse transcriptase (Invitrogen, Carlsbad, CA, USA). Quantitative real-time PCR was carried out using SYBR Green (KAPA Biosystem, Woburn, MA, USA) according to the manufacturer's protocol and reactions were run on the StepOnePlus ${ }^{\mathrm{TM}}$ machine (Applied Biosystems, Foster City, CA, USA). The reaction conditions were $10 \mathrm{~min}$ at $95^{\circ} \mathrm{C}$ for polymerase activation and 40 cycles of $15 \mathrm{~s}$ at $95^{\circ} \mathrm{C}$ and $60 \mathrm{~s}$ at $60^{\circ} \mathrm{C}$. The following primers were used to amplify target genes: human ICAM-1 forward (5'-GCAC ATTGGTTGGCTATCTTCT-3'), ICAM-1 reverse (5'-GCC CGAAGCGTTTACTTTGA-3'), human VCAM-1 forward (5'-GGGACCACATCTACGCTGACA-3'), VCAM-1 reverse (5'-CCTGTCTGCATCCTCCAGAAA-3'), human GAPDH forward (5'-AGGGCTGCTTTTAACTCTGGT-3'), GAPDH reverse (5'-CCCCACTTGATTTTGGAGGGA-3') $[83,84]$. The expression levels of ICAM-1 or VCAM-1 were determined by normalizing to that of GAPDH. The threshold cycle $(\mathrm{Ct})$ was set above the non-template control background and within the linear phase of amplification of target genes in order to calculate the cycle numbers at which the transcript was detected (denoted $\mathrm{Ct}$ ). Each sample was assayed in triplicate and the data shown are representatives of three independent experiments.

\section{Transient transfection of small interfering RNA (siRNA)}

siRNA of human ICAM-1 and EGFR as well as a non-targeting siRNA as a negative control were purchased from Santa Cruz Biotechnology (Santa Cruz, CA, USA). Transient transfection of siRNA (100 nM) was performed using Lipofectamine 2000 Reagent (Invitrogen, Carlsbad, CA, USA) according to the manufacturer's instructions.

\section{Transfection and reporter gene assay}

Human osteosarcoma cells were co-transfected with $0.8 \mu \mathrm{g}$ NF- $\kappa \mathrm{B}$ driven luciferase plasmid and $0.4 \mu \mathrm{g}$ $\beta$-galactosidase expression vector. Cells were grown to $80 \%$ confluence in 12-well plates and were transfected on the following day by Lipofectamine 2000 (LF2000; Invitrogen). DNA and LF2000 were premixed for $30 \mathrm{~min}$ and then were applied to the cells. DMEM containing 20\% FBS was added $4 \mathrm{hr}$ later. After $24 \mathrm{hr}$ of transfection, the cells were treated with the indicated agents. After further $24 \mathrm{hr}$ incubation, the media were removed and cells were washed with cold PBS. To prepare lysates, $100 \mu \mathrm{l}$ reporter lysis buffer (Promega, Madison, WI) were added to each well and cells were scraped from dishes. The supernatant 
was collected after centrifugation at $11,000 \mathrm{~g}$ for $2 \mathrm{~min}$. Aliquots of cell lysates $(20 \mu \mathrm{l})$ containing equal amounts of protein $(20-30 \mu \mathrm{g})$ were placed into wells of an opaque black 96-well microplate. An equal volume of luciferase substrate was added to all samples and luminescence was measured in a microplate luminometer. The level of luciferase activity was normalized to transfection efficiency monitored by the co-transfected $\beta$-galactosidase expression.

\section{Chromatin immunoprecipitation (ChIP)}

ChIP was performed as described [85]. DNA was immunoprecipitated using an anti-p65 antibody and then was extracted, purified, and resuspended in $\mathrm{H}_{2} \mathrm{O}$. Immunoprecipitated DNA was used as template for PCR using the following primers which are specific for the ICAM-1 promoter: 5'-AGACCTTAGCGCGGTGTAGA-3' and 5'-GCGACTCGAGGAGACGATGA-3' [15]. PCR products were resolved by $1.5 \%$ agarose gel electrophoresis and visualized by UV light.

\section{Establishment of stably transfected cells}

The AREG and control shRNA lentiviral constructs (pLKO.1) were obtained from the National RNAi Core Facility (Academia Sinica, Taipei, Taiwan). These two constructs were individually transfected into HEK293T cells along with packaging vectors, $\mathrm{pCMV}$ and pMDG. The cell culture supernatants containing lentiviruses were harvested at $24 \mathrm{hr}$ and $48 \mathrm{hr}$ post-transfection and stored at $-80^{\circ} \mathrm{C}$. The MG63 cells were infected with viral supernatants in the presence of $8 \mu \mathrm{g} / \mathrm{ml}$ of polybrene (Sigma-Aldrich). After $48 \mathrm{hr}$ of infection, the cells were treated with puromycin $(10 \mu \mathrm{g} / \mathrm{ml})$ for selection. The selection medium was replaced every 3 days. After 2 weeks of selection with puromycin, clones of resistant cells were isolated.

\section{In vivo tumor xenograft study}

All animal experiments were performed in accordance with a protocol approved by the Institutional Animal Care and Use Committees (IACUC) of ShinKong Wu Ho-Su Memorial Hospital (Taipei, Taiwan). Male CB17-SCID mice 4-weeks old were used. To assay the metastatic potential of osteosarcoma, $5 \times 10^{6} \mathrm{MG} 63$ transfected cells were resuspended in $0.1 \mathrm{ml}$ of saline and were injected into the tail vein. After injection, visible macroscopic pulmonary metastases were present by 4 weeks and those mice were euthanized by an overdose of the anesthetic agent. The lungs were removed and fixed in $10 \%$ paraformaldehyde. The number of lung tumor metastases was counted under a dissecting microscope.

\section{Statistical analysis}

Statistical significance between two samples was determined by using Student's $t$-test. Statistical comparisons of more than two groups were performed using one-way ANOVA with Bonferroni's post hoc test.

\section{ACKNOWLEDGMENTS}

This work was supported by grants from the National Science Council of Taiwan (NSC-1022314-B-002 -040-MY2; NSC100-2314-B-002-064-MY3), National Taiwan University Hospital (NTUH.104-N2632) and Shin-Kong Wu Ho-Su Memorial Hospital (SKH8302-104-0302). We thank the staff of the Eighth Core Lab, Department of Medical Research, National Taiwan University Hospital for technical support during the study.

\section{CONFLICTS OF INTEREST}

The authors state no conflict of interest.

\section{REFERENCES}

1. Ottaviani G, Jaffe N. The etiology of osteosarcoma. Cancer Treat Res. 2009; 152:15-32.

2. Wang SW, Wu HH, Liu SC, Wang PC, Ou WC, Chou WY, Shen YS, Tang CH. CCL5 and CCR5 interaction promotes cell motility in human osteosarcoma. PloS one. 2012; 7:e35101.

3. Gill J, Ahluwalia MK, Geller D, Gorlick R. New targets and approaches in osteosarcoma. Pharmacology \& therapeutics. 2013; 137:89-99.

4. Bjornland K, Flatmark K, Pettersen S, Aaasen AO, Fodstad O, Maelandsmo GM. Matrix metalloproteinases participate in osteosarcoma invasion. The Journal of surgical research. 2005; 127:151-156.

5. Skubitz AP. Adhesion molecules. Cancer treatment and research. 2002; 107:305-329.

6. Ohene-Abuakwa Y, Pignatelli M. Adhesion molecules in cancer biology. Adv Exp Med Biol. 2000; 465:115-126.

7. Juliano R. Signal transduction by integrins and its role in the regulation of tumor growth. Cancer metastasis reviews. 1994; 13:25-30.

8. Yamamoto H, Irie A, Fukushima Y, Ohnishi T, Arita N, Hayakawa T, Sekiguchi K. Abrogation of lung metastasis of human fibrosarcoma cells by ribozyme-mediated suppression of integrin alpha6 subunit expression. International journal of cancer Journal international du cancer. 1996; 65:519-524.

9. Aoudjit F, Potworowski EF, Springer TA, St-Pierre Y. Protection from lymphoma cell metastasis in ICAM-1 mutant mice: a posthoming event. J Immunol. 1998; 161:2333-2338. 
10. Yang SF, Chen MK, Hsieh YS, Chung TT, Hsieh YH, Lin CW, Su JL, Tsai MH, Tang CH. Prostaglandin E2/EP1 signaling pathway enhances intercellular adhesion molecule 1 (ICAM-1) expression and cell motility in oral cancer cells. J Biol Chem. 2010; 285:29808-29816.

11. Sartor WM, Kyprianou N, Fabian DF, Lefor AT. Enhanced expression of ICAM-1 in a murine fibrosarcoma reduces tumor growth rate. J Surg Res. 1995; 59:66-74.

12. Wedi B, Elsner J, Czech W, Butterfield JH, Kapp A. Modulation of intercellular adhesion molecule 1 (ICAM-1) expression on the human mast-cell line (HMC)-1 by inflammatory mediators. Allergy. 1996; 51:676-684.

13. Hubbard AK, Rothlein R. Intercellular adhesion molecule-1 (ICAM-1) expression and cell signaling cascades. Free radical biology \& medicine. 2000; 28:1379-1386.

14. Maruo Y, Gochi A, Kaihara A, Shimamura H, Yamada T, Tanaka N, Orita K. ICAM-1 expression and the soluble ICAM-1 level for evaluating the metastatic potential of gastric cancer. International journal of cancer Journal international du cancer. 2002; 100:486-490.

15. Chen PC, Lin TH, Cheng HC, Tang CH. CCN3 increases cell motility and ICAM-1 expression in prostate cancer cells. Carcinogenesis. 2012; 33:937-945.

16. Miele ME, Bennett CF, Miller BE, Welch DR. Enhanced metastatic ability of TNF-alpha-treated malignant melanoma cells is reduced by intercellular adhesion molecule-1 (ICAM-1, CD54) antisense oligonucleotides. Experimental cell research. 1994; 214:231-241.

17. Kuai WX, Wang Q, Yang XZ, Zhao Y, Yu R, Tang XJ. Interleukin-8 associates with adhesion, migration, invasion and chemosensitivity of human gastric cancer cells. World journal of gastroenterology: WJG. 2012; 18:979-985.

18. Chen LM, Kuo CH, Lai TY, Lin YM, Su CC, Hsu HH, Tsai FJ, Tsai CH, Huang CY, Tang CH. RANKL increases migration of human lung cancer cells through intercellular adhesion molecule-1 up-regulation. J Cell Biochem. 2011; 112:933-941.

19. Fong YC, Lin CY, Su YC, Chen WC, Tsai FJ, Tsai CH, Huang CY, Tang CH. CCN6 enhances ICAM-1 expression and cell motility in human chondrosarcoma cells. Journal of cellular physiology. 2012; 227:223-232.

20. Hou CH, Lin FL, Tong KB, Hou SM, Liu JF. Transforming growth factor alpha promotes osteosarcoma metastasis by ICAM-1 and PI3K/Akt signaling pathway. Biochemical pharmacology. 2014; 89:453-463.

21. Mendelsohn J, Baselga J. Epidermal growth factor receptor targeting in cancer. Seminars in oncology. 2006; 33:369-385.

22. Pelletier S, Tanguay S, Lee S, Gunaratnam L, Arbour N, Lapointe R. TGF-alpha as a candidate tumor antigen for renal cell carcinomas. Cancer immunology, immunotherapy: CII. 2009; 58:1207-1218.

23. Liu D, Gagliardi G, Nasim MM, Alison MR, Oates T, Lalani EN, Stamp GW, Pignatelli M. TGF-alpha can act as morphogen and/or mitogen in a colon-cancer cell line. International journal of cancer Journal international du cancer. 1994; 56:603-608.

24. Ahmed SR, Badger B, Wright C, Manni A. Role of transforming growth factor-alpha (TGF-alpha) in basal and hormone-stimulated growth by estradiol, prolactin and progesterone in human and rat mammary tumor cells: studies using TGF-alpha and EGF receptor antibodies. The Journal of steroid biochemistry and molecular biology. 1991; 38:687-693.

25. Kullenberg B, Jansen C, Fredang N, Ohlsson B, Axelson J. Transforming growth factor alpha (TGF-alpha) increases cell number in a human pancreatic cancer cell line but not in normal mouse pancreas. International journal of pancreatology: official journal of the International Association of Pancreatology. 2000; 28:199-205.

26. Shoyab M, Plowman GD, McDonald VL, Bradley JG, Todaro GJ. Structure and function of human amphiregulin: a member of the epidermal growth factor family. Science. 1989; 243:1074-1076.

27. Wilson KJ, Mill C, Lambert S, Buchman J, Wilson TR, Hernandez-Gordillo V, Gallo RM, Ades LM, Settleman J, Riese DJ. EGFR ligands exhibit functional differences in models of paracrine and autocrine signaling. Growth Factors. 2012; 30:107-116.

28. Mishra R, Leahy P, Simonson MS. Gene expression profiling reveals role for EGF-family ligands in mesangial cell proliferation. Am J Physiol Renal Physiol. 2002; 283:F1151-1159.

29. Piepkorn M, Lo C, Plowman G. Amphiregulin-dependent proliferation of cultured human keratinocytes: autocrine growth, the effects of exogenous recombinant cytokine, and apparent requirement for heparin-like glycosaminoglycans. Journal of cellular physiology. 1994; 159:114-120.

30. Schuger L, Johnson GR, Gilbride K, Plowman GD, Mandel R. Amphiregulin in lung branching morphogenesis: interaction with heparan sulfate proteoglycan modulates cell proliferation. Development. 1996; 122:1759-1767.

31. Busser B, Sancey L, Brambilla E, Coll JL, Hurbin A. The multiple roles of amphiregulin in human cancer. Biochimica et biophysica acta. 2011; 1816:119-131.

32. Varley C, Hill G, Pellegrin S, Shaw NJ, Selby PJ, Trejdosiewicz LK, Southgate J. Autocrine regulation of human urothelial cell proliferation and migration during regenerative responses in vitro. Experimental cell research. 2005; 306:216-229.

33. Willmarth NE, Ethier SP. Autocrine and juxtacrine effects of amphiregulin on the proliferative, invasive, and migratory properties of normal and neoplastic human mammary epithelial cells. J Biol Chem. 2006; 281:37728-37737.

34. Kenney NJ, Smith GH, Rosenberg K, Cutler ML, Dickson RB. Induction of ductal morphogenesis and lobular hyperplasia by amphiregulin in the mouse mammary gland. Cell Growth Differ. 1996; 7:1769-1781. 
35. Sternlicht MD, Sunnarborg SW, Kouros-Mehr H, $\mathrm{Yu}$ Y, Lee DC, Werb Z. Mammary ductal morphogenesis requires paracrine activation of stromal EGFR via ADAM17-dependent shedding of epithelial amphiregulin. Development. 2005; 132:3923-3933.

36. Qin L, Partridge NC. Stimulation of amphiregulin expression in osteoblastic cells by parathyroid hormone requires the protein kinase A and cAMP response element-binding protein signaling pathway. J Cell Biochem. 2005; 96:632-640.

37. Fukami $T$, Yoshizato $T$, Miyamoto $S$, Yagi $H$, Yotsumoto F, Nabeshima K, Hachisuga T, Kuroki M, Kawarabayashi T. Amphiregulin regulates the production of human chorionic gonadotropin in trophoblasts. Life sciences. 2009; 84:796-804.

38. Solic N, Davies DE. Differential effects of EGF and amphiregulin on adhesion molecule expression and migration of colon carcinoma cells. Experimental cell research. 1997; 234:465-476.

39. Tanaka H, Nishioka Y, Yokoyama Y, Higashiyama S, Matsuura N, Matsuura S, Hieda M. Nuclear envelopelocalized EGF family protein amphiregulin activates breast cancer cell migration in an EGF-like domain independent manner. Biochemical and biophysical research communications. 2012; 420:721-726.

40. Ohchi T, Akagi Y, Kinugasa T, Kakuma T, Kawahara A, Sasatomi T, Gotanda Y, Yamaguchi K, Tanaka N, Ishibashi Y, et al. Amphiregulin is a prognostic factor in colorectal cancer. Anticancer Res. 2012; 32:2315-2321.

41. Kneissl J, Keller S, Lorber T, Heindl S, Keller G, Drexler I, Hapfelmeier A, Hofler H, Luber B. Association of amphiregulin with the cetuximab sensitivity of gastric cancer cell lines. Int J Oncol. 2012; 41:733-744.

42. Mallakin A, Sugiyama T, Kai F, Taneja P, Kendig RD, Frazier DP, Maglic D, Matise LA, Willingham MC, Inoue K. The Arf-inducing transcription factor Dmp1 encodes a transcriptional activator of amphiregulin, thrombospondin-1, JunB and Egr1. International journal of cancer Journal international du cancer. 2010; 126:1403-1416.

43. Willmarth NE, Ethier SP. Amphiregulin as a novel target for breast cancer therapy. J Mammary Gland Biol Neoplasia. 2008; 13:171-179.

44. Yamada M, Ichikawa Y, Yamagishi S, Momiyama N, Ota M, Fujii S, Tanaka K, Togo S, Ohki S, Shimada H. Amphiregulin is a promising prognostic marker for liver metastases of colorectal cancer. Clinical cancer research : an official journal of the American Association for Cancer Research. 2008; 14:2351-2356.

45. Chang CJ, Yin PH, Yang DM, Wang CH, Hung WY, Chi CW, Wei YH, Lee HC. Mitochondrial dysfunctioninduced amphiregulin upregulation mediates chemoresistance and cell migration in HepG2 cells. Cellular and molecular life sciences : CMLS. 2009; 66:1755-1765.
46. Lin TH, Liu HH, Tsai TH, Chen CC, Hsieh TF, Lee SS, Lee YJ, Chen WC, Tang CH. CCL2 increases alphavbeta3 integrin expression and subsequently promotes prostate cancer migration. Biochim Biophys Acta. 2013; 1830:4917-4927.

47. Katerinaki E, Haycock JW, Lalla R, Carlson KE, Yang Y, Hill RP, Lorigan PC, MacNeil S. Sodium salicylate inhibits TNF-alpha-induced NF-kappaB activation, cell migration, invasion and ICAM-1 expression in human melanoma cells. Melanoma research. 2006; 16:11-22.

48. Kesanakurti D, Chetty C, Rajasekhar Maddirela D, Gujrati M, Rao JS. Essential role of cooperative NF-kappaB and Stat3 recruitment to ICAM-1 intronic consensus elements in the regulation of radiation-induced invasion and migration in glioma. Oncogene. 2012.

49. Roche Y, Pasquier D, Rambeaud JJ, Seigneurin D, Duperray A. Fibrinogen mediates bladder cancer cell migration in an ICAM-1-dependent pathway. Thromb Haemost. 2003; 89:1089-1097.

50. Higginbotham JN, Demory Beckler M, Gephart JD, Franklin JL, Bogatcheva G, Kremers GJ, Piston DW, Ayers GD, McConnell RE, Tyska MJ, et al. Amphiregulin exosomes increase cancer cell invasion. Curr Biol. 2011; 21:779-786.

51. Damstrup L, Kuwada SK, Dempsey PJ, Brown CL, Hawkey CJ, Poulsen HS, Wiley HS, Coffey RJ Jr. Amphiregulin acts as an autocrine growth factor in two human polarizing colon cancer lines that exhibit domain selective EGF receptor mitogenesis. British journal of cancer. 1999; 80:1012-1019.

52. Zhou C, Qiu L, Sun Y, Healey S, Wanebo H, Kouttab N, Di W, Yan B, Wan Y. Inhibition of EGFR/PI3K/AKT cell survival pathway promotes TSA's effect on cell death and migration in human ovarian cancer cells. Int J Oncol. 2006; 29:269-278.

53. Jin K, Mao XO, Del Rio Guerra G, Jin L, Greenberg DA. Heparin-binding epidermal growth factor-like growth factor stimulates cell proliferation in cerebral cortical cultures through phosphatidylinositol 3'-kinase and mitogen-activated protein kinase. J Neurosci Res. 2005; 81:497-505.

54. Dengg M, van Meel JC. Caenorhabditis elegans as model system for rapid toxicity assessment of pharmaceutical compounds. J Pharmacol Toxicol Methods. 2004; 50:209-214.

55. Batzer AG, Rotin D, Urena JM, Skolnik EY, Schlessinger J. Hierarchy of binding sites for Grb2 and Shc on the epidermal growth factor receptor. Mol Cell Biol. 1994; 14:5192-5201.

56. Okutani T, Okabayashi Y, Kido Y, Sugimoto Y, Sakaguchi K, Matuoka K, Takenawa T, Kasuga M. Grb2/ Ash binds directly to tyrosines 1068 and 1086 and indirectly to tyrosine 1148 of activated human epidermal growth factor receptors in intact cells. J Biol Chem. 1994; 269:31310-31314. 
57. Jung J, Kim HY, Kim M, Sohn K, Lee K. Translationally controlled tumor protein induces human breast epithelial cell transformation through the activation of Src. Oncogene. 2011; 30:2264-2274.

58. Bonaccorsi L, Carloni V, Muratori M, Formigli L, Zecchi S, Forti G, Baldi E. EGF receptor (EGFR) signaling promoting invasion is disrupted in androgen-sensitive prostate cancer cells by an interaction between EGFR and androgen receptor (AR). International journal of cancer Journal international du cancer. 2004; 112:78-86.

59. Diaz ME, Gonzalez L, Miquet JG, Martinez CS, Sotelo AI, Bartke A, Turyn D. Growth hormone modulation of EGFinduced PI3K-Akt pathway in mice liver. Cell Signal. 2012; 24:514-523.

60. Berg M, Soreide K. EGFR and downstream genetic alterations in KRAS/BRAF and PI3K/AKT pathways in colorectal cancer: implications for targeted therapy. Discovery medicine. 2012; 14:207-214.

61. Hou CH, Tang CH, Hsu CJ, Hou SM, Liu JF. CCN4 induces IL-6 production through alphavbeta5 receptor, PI3K, Akt, and NF-kappaB singling pathway in human synovial fibroblasts. Arthritis Res Ther. 2013; 15:R19.

62. Cuevas BD, Lu Y, Mao M, Zhang J, LaPushin R, Siminovitch K, Mills GB. Tyrosine phosphorylation of p85 relieves its inhibitory activity on phosphatidylinositol 3-kinase. J Biol Chem. 2001; 276:27455-27461.

63. Qiao M, Sheng S, Pardee AB. Metastasis and AKT activation. Cell Cycle. 2008; 7:2991-2996.

64. Tang CH, Tan TW, Fu WM, Yang RS. Involvement of matrix metalloproteinase-9 in stromal cell-derived factor-1/ CXCR4 pathway of lung cancer metastasis. Carcinogenesis. 2008; 29:35-43.

65. Lee CH, Shieh DC, Tzeng CY, Chen CP, Wang SP, Chiu YC, Huang CY, Hsu CJ, Fong YC, Tang CH. Bradykinin-induced IL-6 expression through bradykinin $\mathrm{B} 2$ receptor, phospholipase $\mathrm{C}$, protein kinase Cdelta and NF-kappaB pathway in human synovial fibroblasts. Mol Immunol. 2008; 45:3693-3702.

66. Yong Y, Choi SW, Choi HJ, Nam HW, Kim JA, Jeong DU, Kim DY, Kim YS, Kim DW. Exogenous signal-independent nuclear IkappaB kinase activation triggered by Nkx3.2 enables constitutive nuclear degradation of IkappaB-alpha in chondrocytes. Mol Cell Biol. 2011; 31:2802-2816.

67. LeJeune S, Leek R, Horak E, Plowman G, Greenall M, Harris AL. Amphiregulin, epidermal growth factor receptor, and estrogen receptor expression in human primary breast cancer. Cancer research. 1993; 53:3597-3602.

68. Li S, Plowman GD, Buckley SD, Shipley GD. Heparin inhibition of autonomous growth implicates amphiregulin as an autocrine growth factor for normal human mammary epithelial cells. J Cell Physiol. 1992; 153:103-111.

69. Silvy M, Giusti C, Martin PM, Berthois Y. Differential regulation of cell proliferation and protease secretion by epidermal growth factor and amphiregulin in tumoral versus normal breast epithelial cells. British journal of cancer. 2001; 84:936-945.

70. Menashi S, Serova M, Ma L, Vignot S, Mourah S, Calvo F. Regulation of extracellular matrix metalloproteinase inducer and matrix metalloproteinase expression by amphiregulin in transformed human breast epithelial cells. Cancer research. 2003; 63:7575-7580.

71. P Oc, Modjtahedi H, Rhys-Evans P, Court WJ, Box GM, Eccles SA. Epidermal growth factor-like ligands differentially up-regulate matrix metalloproteinase 9 in head and neck squamous carcinoma cells. Cancer research. 2000; 60:1121-1128.

72. Lee JA, Ko Y, Kim DH, Lim JS, Kong CB, Cho WH, Jeon DG, Lee SY, Koh JS. Epidermal growth factor receptor: is it a feasible target for the treatment of osteosarcoma? Cancer research and treatment : official journal of Korean Cancer Association. 2012; 44:202-209.

73. Blank SV, Chang R, Muggia F. Epidermal growth factor receptor inhibitors for the treatment of epithelial ovarian cancer. Oncology (Williston Park). 2005; 19:553-559.

74. Zhang WQ, Li T, Li H. Efficacy of EGFR tyrosine kinase inhibitors in non-small-cell lung cancer patients with/without EGFR-mutation: evidence based on recent phase III randomized trials. Medical science monitor: international medical journal of experimental and clinical research. 2014; 20:2666-2676.

75. Kersting C, Gebert C, Agelopoulos K, Schmidt H, van Diest PJ, Juergens H, Winkelmann W, Kevric M, Gosheger G, Brandt B, et al. Epidermal growth factor receptor expression in high-grade osteosarcomas is associated with a good clinical outcome. Clinical cancer research: an official journal of the American Association for Cancer Research. 2007; 13:2998-3005.

76. Wen YH, Koeppen H, Garcia R, Chiriboga L, Tarlow BD, Peters BA, Eigenbrot C, Yee H, Steiner G, Greco MA. Epidermal growth factor receptor in osteosarcoma: expression and mutational analysis. Human pathology. 2007; 38:1184-1191.

77. Hsu YL, Huang MS, Cheng DE, Hung JY, Yang CJ, Chou SH, Kuo PL. Lung tumor-associated dendritic cellderived amphiregulin increased cancer progression. Journal of immunology. 2011; 187:1733-1744.

78. Tzeng HE, Tsai CH, Chang ZL, Su CM, Wang SW, Hwang WL, Tang CH. Interleukin-6 induces vascular endothelial growth factor expression and promotes angiogenesis through apoptosis signal-regulating kinase 1 in human osteosarcoma. Biochemical pharmacology. 2013; 85:531-540.

79. Chen JT, Fong YC, Li TM, Liu JF, Hsu CW, Chang CS, Tang CH. DDTD, an isoflavone derivative, induces cell apoptosis through the reactive oxygen species/apoptosis signal-regulating kinase 1 pathway in human osteosarcoma cells. European journal of pharmacology. 2008; 597:19-26. 
80. Tseng WP, Yang SN, Lai CH, Tang CH. Hypoxia induces BMP-2 expression via ILK, Akt, mTOR, and HIF-1 pathways in osteoblasts. J Cell Physiol. 2010; 223:810-818.

81. Liu JF, Fong YC, Chang CS, Huang CY, Chen HT, Yang WH, Hsu CJ, Jeng LB, Chen CY, Tang CH. Cyclooxygenase-2 enhances alpha2beta1 integrin expression and cell migration via EP1 dependent signaling pathway in human chondrosarcoma cells. Molecular cancer. 2010; 9:43.

82. Nowak E, Galilejczyk A, Sypniewski D, Bednarek I. MMP-9 directed shRNAs as relevant inhibitors of matrix metalloproteinase 9 activity and signaling. Postepy higieny i medycyny doswiadczalnej. 2013; 67:742-749.
83. Thornton J, McDaniel LS. THP-1 monocytes up-regulate intercellular adhesion molecule 1 in response to pneumolysin from Streptococcus pneumoniae. Infection and immunity. 2005; 73:6493-6498.

84. Diaz LS, Foster H, Stone MR, Fujimura S, Relman DA, Levy JA. VCAM-1 expression on CD8+ cells correlates with enhanced anti-HIV suppressing activity. J Immunol. 2005; 174:1574-1579.

85. Liu JF, Hou SM, Tsai CH, Huang CY, Yang WH, Tang CH. Thrombin induces heme oxygenase- 1 expression in human synovial fibroblasts through protease-activated receptor signaling pathways. Arthritis Res Ther. 2012; 14:R91. 